\title{
Cross-species testing and utility of microsatellite loci in Indirana frogs
}

\author{
Abhilash Nair ${ }^{1 *}$, Sujith V Gopalan², Sanil George ${ }^{2}$, K Santhosh Kumar $^{2}$ and Juha Merilä ${ }^{1}$
}

\begin{abstract}
Background: Microsatellite loci are widely used in population and conservation genetic studies of amphibians, but the availability of such markers for tropical and subtropical taxa is currently very limited. In order to develop resources for conservation genetic studies in the genus Indirana, we tested amplification success and polymorphism in 62 previously developed microsatellite loci, in eight Indirana species - including new candidate species. Developing genomic resources for this amphibian taxon is particularly important as it is endemic to the Western Ghats biodiversity hotspot, and harbours several endangered species.

Findings: The cross-species amplification success rate varied from $11.3 \%$ to $29.0 \%$ depending on the species, with $29-80 \%$ of the amplifying loci being polymorphic. A strong negative correlation between cross-species amplification success (and polymorphism) and genetic distance separating target from source species was observed.

Conclusions: Our results provide additional genetic support for the existence of genetically divergent cryptic species within the genus Indirana. The tested markers should be useful for population and conservation genetic studies in this genus, and in particular, for species closely related to the source species, I. beddomii.
\end{abstract}

Keywords: Amphibia, Microsatellite, Indirana, Biodiversity hotspot, Ranixalidae, Western Ghats

\section{Background}

The fauna of the Indian Western Ghats biodiversity hotspot is well known for its diversity and high level of endemism [1]. In particular, there are many families and genera of amphibians that are unique to the region $[2,3]$, with roughly 132 endemic species [4]. However, the amphibian diversity in this region remains inadequately characterized [5]. This is reflected by numerous taxonomic uncertainties and ambiguities [6], and in the fact that many species still await proper taxonomic description [7]. Frogs belonging to the endemic genus Indirana (Ranixalidae; [8]) are among the poorly studied amphibian genera from the Western Ghats [9]. At present, information regarding their interspecific and intraspecific differentiation and variability across the diverse and fragmented habitats of Western Ghats is very limited [10].

An earlier study based on the examination of interspecific mitochondrial and nuclear sequence variability

\footnotetext{
*Correspondence: abhilash.nair@helsinki.fi

${ }^{1}$ Ecological Genetics Research Unit, Department of Biosciences, University of Helsinki, PO Box 65, Helsinki Fl-00014, Finland

Full list of author information is available at the end of the article
}

revealed a great deal of cryptic diversity within the Indirana genus; morphologically similar species displayed a high degree $(4.2-17.1 \%)$ of genetic divergence [10]. In order to further explore this differentiation, we have recently developed 62 polymorphic microsatellite loci for one of the Indirana species (I. beddomii; [11]). Here we report the results of cross-species amplification tests for these microsatellite loci in eight other species (including candidate species) within the Indirana genus. Apart from providing information about the cross-species utility of these markers, we also investigated how the amplification success and levels of polymorphism relate to the evolutionary divergence between target and source species.

\section{Methods}

The samples were collected during field surveys in the southern Western Ghats between 2008 and 2010, under licence from National Biodiversity Authority, India (licence \#NBA/TECH Appl/9/85/34/08/08-09/682).

The 62 microsatellite markers to be tested were developed using samples of $I$. beddomii from southern Kerala

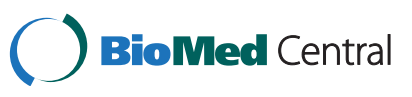




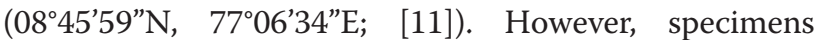
thought to be $I$. beddomii from sites in northern

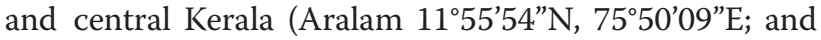
Periyar $09^{\circ} 29^{\prime} 27^{\prime \prime} \mathrm{N}, 7^{\circ} 08^{\prime} 10^{\prime \prime} \mathrm{E}$ ) and Kudremukh in Karnataka $\left(13^{\circ} 12^{\prime} 38^{\prime \prime} \mathrm{N}, 7^{\circ} 11^{\prime} 19^{\prime \prime} \mathrm{E}\right)$ have previously shown high genetic divergence (4.2-12.5\%) from $I$. beddomii frogs from southern Kerala, and from each other [10]. This high genetic divergence suggested that these were cryptic species albeit morphologically similar to each other and to I. beddomii. Therefore, I. beddomii as currently recognized appears not to be a single species, but a complex of at least four distinct species [10]. The same also seems to apply to another species, I. diplosticta [10]. We tested for cross-species microsatellite amplification in four putative species, along with three known species in the genus (I. semipalmata, I. diplosticta, I. leptodactyla), and in an additional unknown species (Indirana sp., Additional file 1). Each primer pair developed for I. beddomii (the "source" species) was tested against all of the "target" species and scored for amplification success and polymorphism. Cross-species amplification tests were performed using 5-10 individuals for each of the eight species/new candidate species within the genus Indirana (Additional file 1).

DNA was extracted from toe clips using a DNeasy Blood and Tissue kit (QIAGEN). Forward primers were labelled with fluorescent dyes FAM, HEX and TET (DNA Technology A/S), and a 5'-GTTT "tail" was added to every reverse primer to facilitate accurate genotyping [12]. PCR reactions were performed for each primer pair in a total reaction volume of $10 \mu \mathrm{L}$ consisting of $1 \times$ QIAGEN Multiplex PCR solution, $0.2-0.3 \mu \mathrm{M}$ of primers, $\mathrm{dH}_{2} \mathrm{O}$ and 10-20 ng of template DNA. The following PCR cycling conditions were used for amplification: $95^{\circ} \mathrm{C}$ for $15 \mathrm{~min}$, followed by 30 cycles of $95{ }^{\circ} \mathrm{C}$ for $30 \mathrm{~s}, 55^{\circ} \mathrm{C}$ for $1.5 \mathrm{~min}, 72{ }^{\circ} \mathrm{C}$ for $1 \mathrm{~min}$, and then a final extension step at $60{ }^{\circ} \mathrm{C}$ for $10 \mathrm{~min}$. The PCR products were diluted 1:100 and electrophoresed on a MegaBACE 1000 capillary sequencer with MegaBACE ET550-R size standard. Genotypes were scored using Fragment Profiler (ver. 1.2; GE Healthcare Life Sciences). The amplification was considered positive if one or two alleles were observed with little or no stutter in comparison to a positive control. Decreasing the PCR annealing temperature is known to increase amplification success and polymorphism detection in cross-species amplification tests [13]. Therefore, markers that did not amplify initially were re-tested for amplification at $52{ }^{\circ} \mathrm{C}$. Annealing temperatures lower than $52{ }^{\circ} \mathrm{C}$ were not used, as they have not proved to be useful in identifying polymorphic loci in earlier cross-species tests [14].

The mitochondrial $16 \mathrm{~S}$ ribosomal RNA gene sequences (466 bp) of Indirana species were retrieved from Genbank [Genbank: JQ596642-44, JQ596648-85]. We used 3-5 sequences per species to estimate the genetic distance between species (i.e. source-target species divergence) based on Kimura two parameter model [15] using MEGA5 [16]. All statistical tests were performed using the program SPSS 15 (SPSS Inc., Chicago IL, USA). The species identity of the individuals used in the study was ascertained using $16 \mathrm{~S}$ sequence as barcodes, following methods described in Nair et al. [10].

\section{Results}

The cross-species amplification tests resulted in successful amplification of 7-18 loci (11.3 - $29.0 \%)$ depending on the species analysed, and 2-14 of these loci were polymorphic in the target species (3.2 - $22.6 \%$; Table 1$)$. Two of the monomorphic loci in the source species $I$. beddomii (IND 11, IND 15) were polymorphic in at least one of the other species, whereas locus IND 24 was monomorphic in all the species (Additional file 1). The

Table 1 Cross-species amplification success rate of the 62 microsatellite loci tested on Indirana species

\begin{tabular}{|c|c|c|c|c|c|c|c|}
\hline Species & $\begin{array}{c}16 \mathrm{~S} \\
\text { divergence }\end{array}$ & $\begin{array}{c}\text { No. of } \\
\text { individuals } \\
\text { tested }\end{array}$ & $\begin{array}{c}\text { No. of } \\
\text { amplifying } \\
\text { loci }\end{array}$ & $\begin{array}{c}\% \\
\text { amplifying }\end{array}$ & $\begin{array}{c}\text { No. of } \\
\text { polymorphic } \\
\text { loci }\end{array}$ & $\begin{array}{c}\% \\
\text { polymorphic }\end{array}$ & $\begin{array}{c}\text { \% of } \\
\text { amplifying } \\
\text { loci which } \\
\text { are polymorphic }\end{array}$ \\
\hline 1. semipalmata & 0.069 & 10 & 15 & 24.2 & 12 & 19.3 & 80.0 \\
\hline Indirana sp* & 0.071 & 10 & 18 & 29.0 & 14 & 22.6 & 77.8 \\
\hline $\begin{array}{l}\text { 1. beddomii * } \\
\text { (Aralam) }\end{array}$ & 0.073 & 10 & 13 & 21.0 & 9 & 14.5 & 69.2 \\
\hline $\begin{array}{l}\text { 1. beddomii* } \\
\text { (Kudremukh) }\end{array}$ & 0.081 & 10 & 16 & 25.8 & 12 & 19.3 & 75.0 \\
\hline $\begin{array}{l}\text { 1. diplosticta* } \\
\text { (Vellarimala) }\end{array}$ & 0.082 & 10 & 13 & 21.0 & 10 & 16.1 & 76.9 \\
\hline $\begin{array}{l}\text { 1. beddomii * } \\
\text { (Periyar) }\end{array}$ & 0.098 & 10 & 16 & 25.8 & 10 & 16.1 & 62.5 \\
\hline 1. leptodactyla & 0.147 & 10 & 7 & 11.3 & 3 & 4.8 & 42.9 \\
\hline 1. diplosticta & 0.175 & 5 & 7 & 11.3 & 2 & 3.2 & 28.6 \\
\hline
\end{tabular}

*new candidate species according to Nair et al. [10]. 
(a)

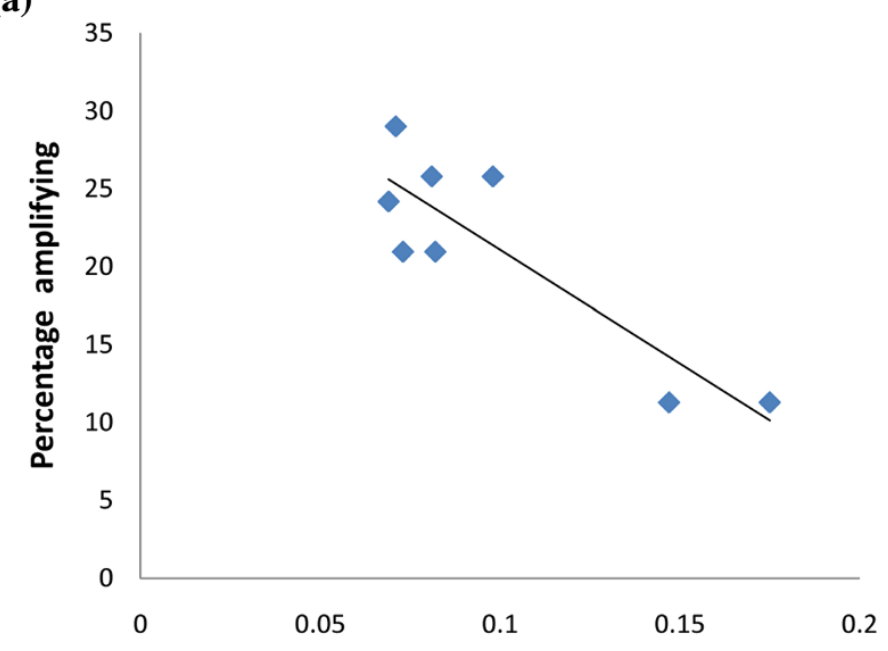

(b)

$16 \mathrm{~S}$ divergence

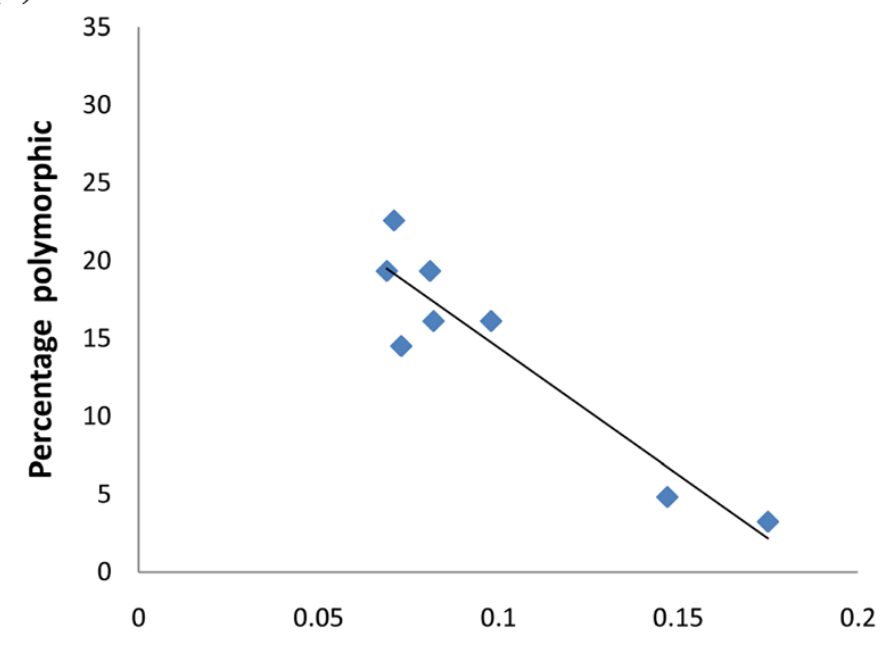

(c)

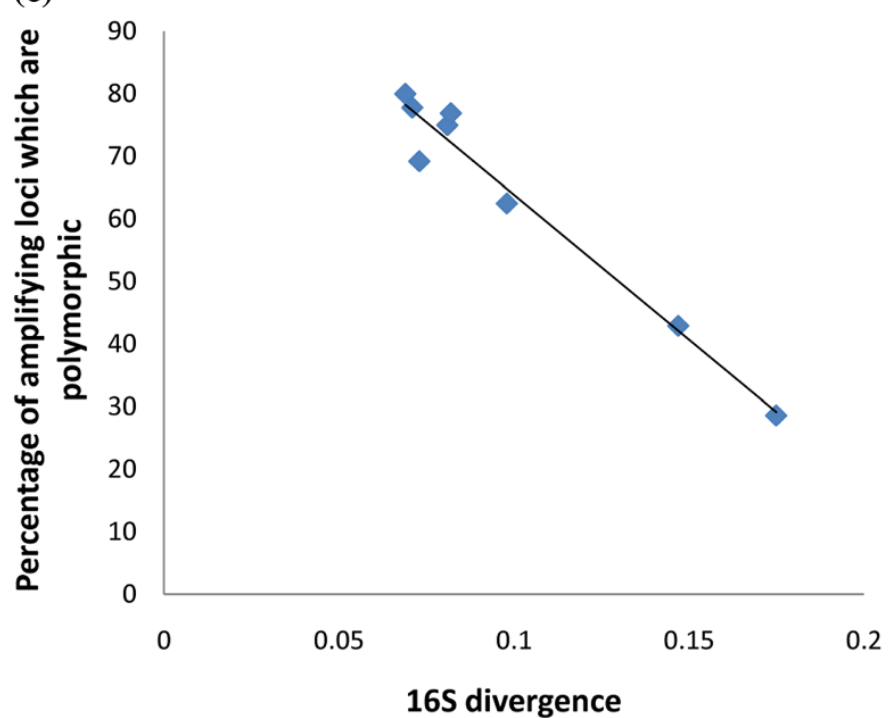

Figure 1 (See legend on next page.) 
(See figure on previous page.)

Figure 1 Relationship between genetic divergence and cross species amplification success. Relationship between (a) percentage of amplifying loci, (b) percentage of polymorphic loci and (c) percentage of amplifying loci which are polymorphic, and the mitochondrial $16 \mathrm{~S}$ divergence from the source species.

genetic divergence between source and target species in $16 \mathrm{~S}$ sequence ranged from 6.9 to $17.5 \%$. The extent of the cross species amplification success $\left(r=-0.87, r^{2}=\right.$ $0.76, P<0.01$; Figure 1a), proportion of the polymorphic loci $\left(r=-0.94, r^{2}=0.88, P<0.01\right.$; Figure $\left.1 \mathrm{~b}\right)$ and polymorphism among amplifying loci $\left(r=-0.98, r^{2}=0.96, P<0.01\right.$, Figure 1c) were strongly negatively correlated with genetic divergence between the target and source species. Lowering the annealing temperature for those initially non-amplifying markers did not result in amplification of any additional loci.

\section{Discussion}

It is well known that the utility of the microsatellites developed for a particular species is a negative function of the genetic distance separating the target and source species $[13,17,18]$, which has been shown in birds, cetaceans, frogs [13] and other amphibians (e.g. [19]). Our results from the Indirana genus conform to these general patterns, and the observed cross-species amplification success rate of $11.3-29.0 \%($ mean $=21.2 \%)$ is comparable to the within-genus amplification success rate of approximately $21 \%$ reported for Ranid frogs [20]. The fact that we found relatively low cross-species amplification success rates of $21.0 \%, 25.8 \%$, and $25.8 \%$ for the three cryptic species that were previously thought to be I. beddomii, supports the idea - based on analyses of multiple nuclear and mitochondrial genes [10] - that the Aralam, Kudremukh and Periyar populations of what was thought to be I. beddomii are indeed distinct species [10].

One of the main reasons for lowered cross-species amplification success is thought to be the lack of conservation of priming sites between highly divergent species [21]. Additionally, increased genome size (C-value) is also known to have a negative effect on cross-species amplification success [22,23]: a decrease in the ratio of target to non-target DNA causes a reduction in amplification efficiency $[24,25]$. Regardless of the proximate cause, the close correspondence between the proportion of amplifying loci and $16 \mathrm{~S}$ divergence among the tested taxa (Figure 1a) - as well as the proportion of polymorphic loci and $16 \mathrm{~S}$ divergence (Figure 1b \& c) - suggests comparable rates of divergence of mitochondrial and nuclear genomes in these frogs. While these patterns are admittedly driven by low amplification success in the two highly divergent species, I. diplosticta and I. leptodactyla (14.7-17.5 \%), the data nonetheless suggests that the cross-species utility of these markers declines with increasing evolutionary distance among taxa. For example, only $2-3$ out the 62 tested loci were found to be polymorphic in the two most divergent taxa, limiting the utility of these markers in studies of divergent Indirana species. Interestingly, one of the loci (IND107) was highly polymorphic in all taxa studied, with similar numbers of alleles observed both in the source and most divergent species (Additional file 1). This locus appears to be conserved in all species within Indirana and could be associated with some functionally important gene. Conservation of microsatellite loci residing within or close to functionally important genes has been reported from other highly divergent species (e.g. [26,27]).

Taken together, the results of this study show that the cross-species amplification success in Indirana frogs depends on the degree of evolutionary divergence between the source and target species, with the success rate and polymorphism declining rapidly with increasing divergence between the taxa. However, given the relatively high levels of microsatellite polymorphism in some of the target species, these markers may provide useful tools for future conservation genetic studies aiming to address taxonomic uncertainties, or to study genetic variability and differentiation of Indirana populations.

\section{Additional file}

Additional file 1: Cross species amplification of microsatellite loci in eight species from the Indirana genus. $A=$ number of alleles observed, $n=$ number of individuals tested. A dash indicates no amplification success.

\section{Competing interests}

Authors declare that they have no competing interests.

\section{Author contributions}

AN, SG and JM conceived the study. SVG, SG and KSK collected all the samples. AN performed all the experiments, analyses and had a major role in writing the manuscript together with JM. All authors contributed to and approved the final manuscript.

\section{Acknowledgements}

We thank Marika Karjalainen and Kirsi Kähkönen for assistance in laboratory and Jacquelin DeFaveri for language editing. We are grateful to Kerala and Karnataka Forest Departments for permissions for sample collections. Thanks are due to Vinodlal K. S., Vijayan P. and Biju S. Nair for help with the field work, and Amber Teacher and Takahito Shikano for discussions and helpful comments on earlier versions of this manuscript. This study was funded by Academy of Finland (grant \#125092 to JM) and Department of

Biotechnology, Government of India (BT/IN/Finnish/11/SG/2008 to SG).

\section{Author details}

${ }^{1}$ Ecological Genetics Research Unit, Department of Biosciences, University of Helsinki, PO Box 65, Helsinki Fl-00014, Finland. ${ }^{2}$ Chemical Biology, Rajiv Gandhi Centre for Biotechnology, PO Thycaud, Poojappura,

Thiruvananthapuram, Kerala 695 014, India. 
Received: 16 May 2012 Accepted: 13 July 2012

Published: 29 July 2012

\section{References}

1. Myers N, Mittermeier RA, Mittermeier CG, da Fonseca GAB, Kent J: Biodiversity hotspots for conservation priorities. Nature 2000, 403:853-858.

2. Biju SD, Bossuyt F: New frog family from India reveals an ancient biogeographical link with the Seychelles. Nature 2003, 425:711-714.

3. Daniels RJR: Amphibians of Peninsular India. Hyderabad: Universities Press (India) Private Ltd; 2005.

4. Dinesh KP, Radhakrishnan C, Gururaja KV, Bhatt G: An annotated checklist of Amphibia of India with some insights into the patterns of species discoveries, distribution and endemism. Rec Zool Surv India 2009, 302:1-133.

5. Inger RF: Distribution of amphibians in southern Asia and adjacent islands. In Patterns of Distribution of Amphibians: A global perspective. Edited by Duellman WE. London: The Johns Hopkins University Press; 1999:445-482.

6. Daniels RJR: Taxonomic uncertainties and conservation assessment of the Western Ghats. Curr Sci 1997, 73:169-170.

7. Biju SD: A synopsis to the frog fauna of the Western Ghats. India. Occas Publ Indian Soc Conserv Biol 2001, 1:1-24.

8. Bocxlaer IV, Roelants K, Biju SD, Nagaraju J, Bossuyt F: Late Cretaceous vicariance in Gondwanan amphibians. PLoS One 2006, 1:e74

9. Nair A, Gopalan SV, George S, Kumar KS, Teacher AGF, Merilä J: Endemic Indirana frogs of the Western Ghats biodiversity hotspot. Ann Zool Fenn, in press.

10. Nair A, Gopalan SV, George S, Kumar KS, Teacher AGF, Merilä J: High cryptic diversity of endemic Indirana frogs in the Western Ghats biodiversity hotspot. Anim Conserv, doi:10.1111/j.1469-1795.2012.00539.x.

11. Nair A, Kumar KS, George S, Gopalan SV, Li M-H, Leder E, Merilä J: Sixty two new microsatellite markers for an endemic frog Indirana beddomii from the Western Ghats biodiversity hotspot. Conserv Genet Resour 2011, 3:167-171.

12. Brownstein MJ, Carpten JD, Smith JR: Modulation of non-templated nucleotide addition by TaqDNA polymerase: primer modification that facilitate genotyping. BioTechiques 1996, 20:1004-1010.

13. Primmer CR, Painter JN, Koskinen MT, Palo JU, Merilä J: Factors affecting avian cross-species microsatellite amplification. J Avian Biol 2005, 36:348-360.

14. Liu Z, Crooijmans RPMA, van der Poel JJ, Groenen MAM: Use of chicken microsatellite markers in turkey: A pessimistic view. Anim Genet 1996, 27:191-193.

15. Kimura MA: A simple method for estimating evolutionary rate of base substitutions through comparative studies of nucleotide sequences. J Mol Evol 1980, 16:111-120.

16. Tamura K, Peterson D, Peterson N, Steker G, Nei M, Kumar S: MEGA5: Molecular Evolutionary Genetics Analysis using Maximum Likelihood, Evolutionary Distance, and Maximum Parsimony Methods. Mol Biol Evol 2011, 28:2731-2739.

17. Moore SS, Sargeant LL, King TJ, Mattick JS, Georges M, Hetzel DJS: The conservation of dinucleotide microsatellites among mammalian genomes allows the use of heterologous PCR primer pairs in closely related species. Genomics 1991, 10:654-660.

18. Carreras-Carbonell J, Macpherson E, Pascual M: Utility of pairwise mtDNA genetic distances for predicting cross-species microsatellite amplification and polymorphism success in fishes. Conserv Genet 2008, 9:181-190.

19. Hendrix R, Hauswaldt S, Veith M, Steinfartz S: Strong correlation between cross-amplification success and genetic distance across all members of "True Salamanders" (Amphibia: Salamandridae) revealed by Salamandra salamandra-specific microsatellite loci. Mol Ecol Resour 2010, 10:1038-1047.

20. Primmer CR, Merilä J: A low rate of cross-species microsatellite amplification success in ranid frogs. Conserv Genet 2002, 3:445-449.

21. Balloux F, Ecoffey E, Fumagalli L, Goudet J, Wyttenbach A, Hausser F: Microsatellite conservation, polymorphism, and GC content in shrews of the genus Sorex (Insectivora, Mammalia). Mol Biol Evol 1998, 15:473-475.

22. Garner TWJ, Schmidt BR, Hoeck P, Van Buskirk J: Di- and tetranucleotide microsatellite markers for the Alpine newt (Triturus alpestris): characterization and cross-priming in five congeners. Mol Ecol Notes 2003, 3:186-188.

23. Barbará T, Palma-Silva C, Paggi GM, Bered F, Fay MF, Lexer C: Cross-species transfer of nuclear microsatellite markers: potential and limitations. Mol Ecol 2007, 16:3759-3767.

24. Farrelly V, Rainey FA, Stackebrandt E: Effect of genome size and rrn gene copy number on PCR amplification of 16S rRNA genes from a mixture of bacterial species. Appl Environ Microbiol 1995, 61:2798-2801.

25. Garner TWJ: Genome size and microsatellites: the effect of nuclear size on amplification potential. Genome 2002, 45:212-215.

26. Moore SS, Hale P, Bryne K: NCAM: a polymorphic microsatellite locus conserved across eutherian mammal species. Anim Genet 1998, 29:33-36

27. Shikano T, Ramadevi J, Shimada Y, Merilä J: Utility of sequenced genomes for microsatellite marker development in non-model organisms: a case study of functionally important genes in nine-spined sticklebacks (Pungitius pungitius). BMC Genomics 2010, 11:334.

doi:10.1186/1756-0500-5-389

Cite this article as: Nair et al:: Cross-species testing and utility of microsatellite loci in Indirana frogs. BMC Research Notes 2012 5:389.

\section{Submit your next manuscript to BioMed Central and take full advantage of:}

- Convenient online submission

- Thorough peer review

- No space constraints or color figure charges

- Immediate publication on acceptance

- Inclusion in PubMed, CAS, Scopus and Google Scholar

- Research which is freely available for redistribution

Submit your manuscript at www.biomedcentral.com/submit
C BioMed Central 